\title{
INFLUENCING BECKETT / BECKETT INFLUENCING
}

2017. június 15-17. között került sor az International Federation for Theatre Research Samuel Beckett Working Group munkacsoportjának angol nyelvü mühelytalálkozójára Beckett Influencing / Influencing Beckett címmel. A program a Károli Gáspár Református Egyetem (KRE) és az Îr Nagykövetség támogatásával valósult meg. Három évvel később, az elhangzott előadások anyagából megjelent tanulmánykötet ennek a rendhagyó találkozónak állít emléket.

Hatását tekintve Samuel Beckett (1906-1989) a 20. század Shakespeare-jének mondható. A színpadi múvei okozta sokkhatás alól a mai napig nem ocsúdott fel a színház világa. Nevéhez köthető az az 1950-es évektől kibontakozó színháztörténeti korszak, amelyet Martin Esslin abszurd színháznak (Theatre of the Absurd) nevezett főmüvében, és amelyben más, Becketthez hasonlóan Párizsban élő és alkotó szerzők, Eugène Ionesco, Arthur Adamov és Jean Genet is szerepet játszottak. A Beckett-kutatók ma különböző iskolákba tömörülnek, akárcsak az egyes Shakespeare-irányzatok. A nemek tudományától a fordításelméletig, a filozófiától a technológiáig, a természet szerepétől az ökokritikáig a konferenciatémák sorát hosszan folytathatnánk. A Beckettről írt szakirodalmak bő választéka egyszerre inspiráló és frusztráló a szerzővel foglalkozó irodalomtudós számára. A róla szóló tanulmányoknak egyik fontos lelőhelye a JOBS (Journal of Beckett Studies), a másik a Samuel Beckett Today / Aujourd'hui. Mondani sem kell, hogy emellett számos tanulmánykötet és monográfia jelenik meg müveiről minden évben.

Beckett ugyanakkor nem pusztán íróként alkotott maradandót, hanem emberi kvalitásait tekintve is megmarad az utókor emlékezetében. A szintén Nobel-díjas abszurd drámaíró, Harold Pinter (1930-2008) felidézi egy találkozását Beckett-tel, amikor Párizs egy kávézójában ültek és beszélgettek. Estefelé járt, amikor Pinter rosszul lett, olyan hasfájás vett erőt rajta, hogy lefeküdt az asztalra, és félig önkívületbe esett. Elbeszélése szerint Beckett ekkor felállt, és szó nélkül távozott. Néhány óra elteltével azonban visszatért, miután sikerült a többnyire zárt boltok ellenére szódabikarbónát szereznie. Kortárs mủvészek, barátok, irodalomtörténészek hada számol be hasonló tapasztalatokról vele kapcsolatban. Mindennek fényében egy közvetlen, udvarias és nagylelkủ személyiség tárul elénk, aki ugyan nem türt meg semmilyen eltérést a szerzői instrukcióitól, ha egy előadásról volt szó (ebben szinte zsarnok ként ragaszkodott a legapróbb részletekhez), de civilként készséges segíteni akarás, empátia és elózékenység jellemezte. A rendelkezésre álló információk alapján úgy tủnik, távol állt tőle minden szakmai felsőbbrendủség, sznobéria vagy rivalizálás. Nagy öröm, hogy 2017-ben Budapesten egy olyan konferencia jöhetett létre, amely hủ Beckett alkotói és emberi oldalához egyaránt. 
Azoknak, akik úgy gondolják, hogy az abszurd dráma egy elavult korszak, a színháztörténet mára meghaladott fejezete, és esetleg értetlenül tekintenek egy ilyen konferenciára a 21. században, szíves figyelmébe ajánlom Tompa Gábor rendező máig érvényes szavait (idézi Rákóczy Anita a tanulmánya bevezetőjében): „Nem tudom, hogy aki azt állítja, lejárt az abszurd drámák kora, hol él és milyen időben, talán már nem is él. Az abszurd kategóriájában éppúgy benne van Shakespeare Troilus és Cressidája, Csehov Három növére, Cseresnyéskertje, mint Ionesco, Beckett, Mrożek, Gombrowicz müvei. Vagyis azoknak az apokaliptikus időknek a szerzői, amelyekben élünk." Vitatkozni lehet az abszurd ilyen mértékủ müfaji kiterjesztésével, amely sajnálatos módon már Martin Esslin alapmủvében is megfigyelhető, de máig fennálló töretlen relevanciájával aligha.

A Samuel Beckett Munkacsoport (Samuel Beckett Working Group, SBWG) találkozója Budapesten nemcsak önmagában volt örvendetes és bizonyos értelemben példaértékü esemény, hanem szakmai, elsősorban irodalomtudományi és színháztörténeti súlyát tekintve is. Amellett, hogy az SBWG huszonegy éves fennállását hazánkban ünnepelhette a háromnapos konferencia keretei között, az alkalom különlegességét elsősorban nem ez adta. Nem is az, hogy a mühelytalálkozón a világ távoli pontjairól érkező irodalomtudósok oszthatták meg egymással kutatásaik eredményeit. Ez szinte bármelyik nemzetközi konferenciáról elmondható. Különlegessége egyrészt abban állt, amit a könyv előszavában Linda Ben-Zvi az SBWG-találkozók és megbeszélések egalitariánus és nyitott szellemiségének nevez. Ezeken a workshopokon egyrészről ismert, másrészről pályájuk elején járó Beckett-kutatók kaptak lehetőséget nézeteik ütköztetésére, gondolataik megvitatására azonos keretek között, a konferenciákon világszerte tapasztalható szakmai hierarchia nélkül. A találkozó nem hétköznapi jellegét mutatta a konferenciákon megszokott futószalagszerü menetrendtől való látványos eltérés is. A résztvevők előre megkapták egymás írásait, így azok ismertetésére elegendő volt az átlagosnál szűkebb időkeret. A hangsúly az egyes kutatási eredmények termékeny és proaktív tárgyalásán és a feedbacken volt, amelyre ennélfogva több idő jutott. A könyv ennek az izgalmas közös munkának az eredménye. Meg kell ugyanakkor említeni az egalitariánus szemlélet árnyoldalát is. Bár egy mühelymunka kétségkívül alkalmat adhat félkész kutatások és még kiforratlan gondolatkísérletek megbeszélésére, pályakezdő doktoranduszok és elismert szakértők eszmecseréjére, a kötetbe végül beválogatott írásokat jobban is meg lehetett volna szürni. Meglehetősen vegyes színvonalú tanulmányok alkotják a kiadványt, és olykor az az érzése az olvasónak, hogy hallgatóként jobban le volt nyügözve.

Ugyanakkor a magyar résztvevők és általában véve a hazai szakmai élet számára a találkozó legfőbb kuriózuma abban állt, hogy ez volt az első Magyarországon rendezett nemzetközi Beckett-konferencia. A szervezőknek, Rákóczy Anitának (Károli Gáspár Református Egyetem), Mariko Hori Tanakának (Aojama 
Gakuin Egyetem, Tokió) és Linda Ben-Zvinek (professor emerita, Coloradói Állami Egyetem és Tel-Avivi Egyetem) köszönhetően a magyar színházkutatóknak lehetőségük nyílt a Károli Egyetemen, hogy elméleti és gyakorlati téren végzett munkájukat nagyobb nyilvánosság előtt is bemutathassák, és bekapcsolódhassanak egy kontinenseken átívelő kulturális párbeszédbe. Ennek keretében kiemelt jelentőséggel bírt a magyar résztvevők találkozása az angliai Readingi Egyetem Beckett-kutatóival. Az egyetem nem kizárólag az ott tanító nemzetközi szaktekintélyek miatt fontos bástyája a Beckett-kutatásnak, hanem az ott található Beckett-archívum miatt is, ahol többen is végeztek kutatásokat az előadók közül. Ezenkívül, amint azt a könyv szerkesztői (Rákóczy Anita, Mariko Hori Tanaka és Nicholas E. Johnson) a bevezetőben megjegyzik, az esemény célja további Beckettel kapcsolatos kutatások és színházi előadások szorgalmazása Magyarországon, valamint Beckett jelentőségének tudatosítása az oktatásban. E missziós tevékenység nélkülözhetetlen eszköze ez a könyv.

A Károli Gáspár Református Egyetem könyvkiadási rendszere 2011-ben megújult. Ekkor indult el az egyetem és a L'Harmattan Kiadó közös sorozata, a Károli Könyvek, amely öt alsorozatra tagolódik: Monográfia, Tanulmánykötet, Müfordítás, Idegen nyelvü sorozat és Jegyzet. A sorozatszerkesztő dr. Sepsi Enikő profeszszor, a Bölcsészettudományi Kar dékánja. A 2020-ban megjelent Beckett-könyv a Tanulmánykötet alsorozat 72. (!) kötete. Dicséretes és példamutató az egyéni és közös kutatások ilyen mértékű felkarolása és megjelenítése.

Mivel a téma meglehetősen tág és nehezen összefogható, a szerkesztők bölcsen három részre osztották a kötetet: az első részben a Beckett művészetére ható különböző elméleti, filozófiai és esztétikai műveket tárgyaló írásokat találjuk. Olvashatunk arról, hogyan formálta Beckett világképét Marcel Proust; a holland festő testvérpár, Bram és Geer Van Velde, valamint Jean-Paul Sartre, és nem utolsósorban a kínai filozófia és a buddhizmus. A második részben Beckett kortársaira és későbbi szerzőkre gyakorolt hatását elemző tanulmányok sorakoznak. Ezek az írások Beckett szerepét és örökségét vizsgálják Harold Pinter korai drámáinak recepciójában; Caryl Churchill kései darabjaiban; a már említett romániai magyar származású rendező, Tompa Gábor színpadi elképzeléseiben; és Bruce Nauman, a kísérletező amerikai polihisztor művészetében. A tematikus blokk utolsó tanulmánya a csend színpadi megjelenésformáit vizsgálja Beckett, Anton Csehov és Hirata Oriza, 21. századi japán drámaíró színházában. Végül, a harmadik rész a színházi gyakorlatra fókuszáló esszéket tartalmazza. Itt kapott helyet két tanulmány, amelyben magyar dramaturgok és fordítók mutatják be a Beckett kezdeti magyarországi fogadtatását meghatározó tevékenységüket. Ezek az írások a személyes érintettség közvetlensége és a konkrét érzelmi töltés folytán új színt visznek a könyv tudományos diskurzusok által uralt világába. A kötetet három ír szerző közös tanulmánya zárja a technológiai újítások és a digitális kultúra adta lehetőségekről egy Beckett-darab előadása kapcsán. 
A KRE és a L’Harmattan Kiadó legfrissebb kiadványa szépen és átláthatóan felépített, a fent megfogalmazott fenntartások ellenére komoly szakkönyv, amely számot tarthat mindazok érdeklődésére, akik szeretnének eligazodni a nemzetközi Beckett-kutatás szerteágazó irányzataiban. Emellett betekintést ad az ír szerző világképét és művészetét meghatározó esztétikai, filozófiai és irodalomtörténeti hagyományokba, és segít megérteni műveinek maradandó színház- és kultúrtörténeti hatását.

(Anita Rákóczy-Mariko Hori Tanaka - Nicholas E. Johnson editors: Influencing Beckett / Beckett Influencing. Collection of Papers. Collection Károli. BudapestParis: KRE-L'Harmattan, 2020, 162 o.).

Nyusztay lván egyetemi adjunktus, Eötvös Loránd Tudományegyetem 